\title{
健康な地域住民における脈波速度と 炎症マーカーの関連性について
}

\author{
佐 藤 浩 子, ${ }^{1,2}$ 佐 藤 真 人, ${ }^{1,3}$ 坂 本 浩之助 ${ }^{1,4}$ \\ 澤 田 芳 枝, ${ }^{1}$ 星 野 綾 美, $^{1}$ 宮 崎 有紀子 ${ }^{5}$ \\ 佐 藤 久美子, ${ }^{5}$ 小 暮 敏 明, ${ }^{2}$ 倉 林 正 彦 ${ }^{6}$ \\ 田 村 遵一 1
}

\begin{abstract}
要 旨
【目 的】動脈硬化症では, 脈波速度 (PWV) は増大し, 高感度 CRP (hsCRP) やインターロイキン 6 (IL-6) 等の炎症マーカーも高值を示す. 本研究では, 健康な地域住民において, PWV と炎症マーカーとの関連性を 検討した.【対象と方法】対象は，2003 年 8 月から 2004 年 1 月までに群馬県吉岡町の健康相談に参加した 地域住民 109 名であった。動脈硬化の進展度を反映する上腕一足首 PWV (baPWV) を計測するとともに， hsCRP，IL-6の血中濃度を測定し， baPWV と炎症マーカーの相関関係の有無を検討した. 【結 果】 baPWV は, hsCRP 及び IL-6 との間に有意な正の相関を示した. また, baPWV が $13.7 \mathrm{~m} / \mathrm{sec}$ 以上の参加者で は IL-6が有意に高值であった。【結 語】健常人においても血管壁の炎症が潜在的な動脈硬化を惹起する 可能性が示唆された. IL-6 は初期段階の動脈硬化の予知に有用と思われた.（Kitakanto Med J 2006；
\end{abstract} $56: 201 \sim 206)$

キーワード：健常者, 健康相談, 脈波速度, 炎症, 動脈硬化

\section{は じめに}

心筋梗塞, 狭心症, 脳梗塞などの血管病は, 日本人の生 命予後や機能予後を著しく低下させる要因のひとつであ り，その成因として動脈硬化の関与が知られている。そ して, 現代医学の発展にもかかわらず, 心血管病による 年次死亡率は癌と並んで増加の一途をたどっている. 動 脈硬化を予防するためには, 高血圧, 高脂血症, 糖尿病, 喫煙などの危険因子を減らすとともに, 食事や運動など の生活習慣の改善が重要である.その一方で, 血管病の 発症前の早期に動脈硬化の進展度を評価することができ れば，血管病発症の予防のみならず，健康に対する国民 の意識の向上に大いに役立つと考えられる。

近年, 脈波速度 (pulse wave velocity；PWV) が動脈硬 化のスクリーニング指標として注目を集めている. ${ }^{1,2}$
PWV は心臓から大動脈に駆出された血液が動脈の中を 運搬されるときに発生する波動が血管壁を伝わる速さで あり,その值が大きいほど血管は硬く, 動脈硬化が進ん でいることを意味する.PWV は加齢や血圧上昇に伴っ て増大し, 高血圧, 糖尿病, 腎不全に扔いては心血管イ心゙ ントの有力な予知因子となることが報告されている ${ }^{3,4}$. 従来の頸動脈一大腿動脈 PWV (carotid-femoral PWV; cfPWV) の計測には熟練を要し,プライマリケア医が日 常診療で用いるのは困難であった. しかし, 四肢に血圧 測定用のカフを装着するのみで上腕一足首 PWV (brachial-ankle PWV; baPWV) を全自動で計測する装置が 開発されるに至り，広範囲の臨床応用が可能になった.

一方, 血管分子生物学の研究成果から, 動脈硬化は血 管壁の炎症として理解されるようになった. ${ }^{5,6}$ 高コレス テロール血症患者にみられる低比重リポ蛋白 (LDL) の

1 群馬県前橋市昭和町3-39-15 群馬大学医学部附属病院総合診療部 2 群馬県前橋市昭和町3-39-15 群馬大学医学部統合和漢 診療学講座 3 群馬県前橋市昭和町3-39-22 群馬大学大学院医学系研究科器官機能構築学講座 4 群馬県高崎市中大類町 501 高崎健康福祉大学看護学部 5 群馬県前橋市昭和町3-39-22 群馬大学医学部保健学科 6 群馬県前橋市昭和町3-39-22 群馬 大学大学院医学系研究科藏器病態内科学

平成18年 3 月 30 日 受付

論文別刷請求先 $\overline{\mathbf{T}} 370-0033$ 群馬県高崎市中大類町501 高崎健康福祉大学看護学部 坂本浩之助 
過剩状態では, 酸化 LDL が血管壁内に取り込まれるや, 末梢単球がその処理のために血管壁内に遊走し炎症を惹 起する. ${ }^{5}$ また, 高血圧による動脈硬化の進展においても 炎症は重要な役割を果たしており，血管壁にかかる“ず り応力”や“伸展刺激”などの物理的刺激は末梢単球を マクロファージへと成熟分化させ, 炎症性サイトカイン の産生を促進する.7 血管壁における炎症の指標としては 高感度 CRP (high-sensitive C-reactive protein ; hsCRP) があり, ${ }^{8}$ 総コレステロール值と並んで血管病の独立した 危険因子として認められている. ${ }^{9} \mathrm{CRP}$ の主な産生部位 は肝臓であるが, 動脈硬化病変に局在するマクロファー ジや平滑筋細胞においても CRP 遺伝子の過剩発現が報 告されている. ${ }^{10} \mathrm{CRP}$ 以外に, インターロイキン 6 (interleukin-6；IL-6) や血清アミロイド A 蛋白などの炎症 マーカーも, 動脈硬化性疾患で血中濃度が上昇すること が明らかになっている. ${ }^{8,11}$

炎症マーカーと baPWV との関連性については, 末期 腎不全患者において hsCRP と baPWV との間に有意な 正の相関が報告されている. ${ }^{12}$ 英国で行われた健常人 432 例を対象とした疫学研究に扔いても, 年齢, 平均血圧と 並んで, hsCRP はPWV と強く相関することが示されて いる.13 しかしながら，わが国に扔いては，炎症マーカー と baPWV との関連性を健常人で検討した報告は見当た らず，この関連性が明らかになれば，健常人における早 期の動脈硬化の発見に炎症マーカーを活用できる可能性 がある.また，このような疫学研究は地域住民の健康へ の意識の向上にも役立つことが期待される. 今回, 群馬 県内の健康な地域住民を対象として動脈硬化の進展度を 反映する baPWV の計測と炎症マーカーの血中濃度の測 定を行い，その関連性について検討したので報告する.

\section{対象と方法}

\section{対 象}

群馬大学医学部附属病院総合診療部は, 2003 年 8 月か ら 2004 年 1 月までの期間に群馬県北群馬郡吉岡町にお いて健康相談を実施した. 対象は, 町の広報を読んで健 康相談に参加した健康な地域住民 145 例 (平均年齢 52 . $9 ・ 12.9$ 歳, 男性 37 例, 女性 108 例) である. このうち, 高 血圧, 糖尿病, 腎不全, 炎症性疾患と診断されている住民, 心筋梗塞, 狭心症, 脳梗塞の既往のある住民は統計解析 の対象から除外した. 一方, 多数の研究で, PWV と総コ レステロール值との間には有意の関連性を認めないと報 告されており，高脂血症を合併する住民は統計解析の対 象として登録した. 最終的な統計解析の対象者は 109 例 であった.

\section{倫理的配慮}

健康相談は十分な説明の上，書面によるインフォーム ドコンセントを得て, 各人ごとに同意の得られた検査の みを行った。

\section{健康相談の内容}

参加者には，はじめに健康に関するアンケート調査を 実施した。質問内容は, 既往歴, 家族歷, 喫煙歴, 飲酒歴, 現在治療中の病気の有無, 服薬歴の 6 項目とした. 次に, 血圧測定, baPWV 測定, 血液検查を実施した. 血液検查 の内容は, hsCRP, IL-6, 血清アミロイド A 蛋白, 総コレ ステロールの 4 項目とした. hsCRP はラテックス免疫比 濁法, IL-6 は化学発光酵素免疫測定法, 血清アミロイド $\mathrm{A}$ 蛋白はラテックス凝集免疫法, 総コレステロールは酵 素法にて測定した. 血液は静脈採血後, 3,000 回転, 10 分 間, $4^{\circ} \mathrm{C} て ゙$ 遠心分離し, 血清を測定時までー $30^{\circ} \mathrm{C} て ゙$ 凍結保 存した.

\section{脈波速度の計測}

baPWV および四肢の血圧は，血圧脈波検査装置 VS -1000 (フクダ電子, 東京) を用いてオシロメトリック法 により計測した。

\section{統計解析}

数值は平均值・標準偏差で表記した. 統計解析は統計 ソフトStatView 5.0 日本語版 (ヒューリンクス, 東京) を 用いて行った. baPWV と, 年齢 - 収縮期血圧 - 拡張期血 圧・総コレステロール・hsCRP・IL-6 との関連性の検定 にはPearsonの相関係数を用いた，その際, デー夕が正規 分布に従わなかった baPWV, hsCRP, IL-6の 3 項目は, それぞれ対数変換し正規分布することを確認してから検 定した. 一方, 対数変換後もなお正規分布に従わなかっ た血清アミロイド A 蛋白は検定の対象から除外した.さ らに，対象を baPWV の值により 0 ２5\%值 (A1)，26 $\sim 50 \%$ 值 (A2), 51 75\%値 (A3), 76〜100\%值 (A4) の 4 つの階層に分け, hsCRP と IL-6の 2 項目について baPWV 階層間で差があるかを評価した. はじめに分散 分析 (Kruskal-Wallis one way ANOVA) を行い有意差 が認められた場合に, Wilcoxon rank-sum test で多重比 較検定を行った。すべてのテストで危険率 $\mathrm{p}<0.05$ を もって統計学的に有意であると判定した.

結果

\section{参加者の臨床背景}

表 1 亿参加者の臨床背景を示す. 最終的な統計解析の 対象者は 109 例 (男性 30 例, 女性 79 例) であった.この うち, 65 歳以上の老年者は 27 人であった. また, 高血圧 
(140/90 mmHg 以上と定義する) は 33 例, 高コレステ ロール血症 $(220 \mathrm{mg} / \mathrm{dl}$ 以上と定義する $)$ は 37 例にみら れた。

Table 1 Baseline characteristics of the study participants.

\begin{tabular}{lc}
\hline & Mean $(\mathrm{SD})$ \\
\hline Age $(\mathrm{y})$ & $51.2(12.8)$ \\
Gender (Male/Female) & $30 / 79$ \\
Systolic Blood Pressure $(\mathrm{mmHg})$ & $127.4(17.7)$ \\
Diastolic Blood Pressure $(\mathrm{mmHg})$ & $79.8(12.5)$ \\
Height $(\mathrm{cm})$ & $158.6(8.2)$ \\
Weight $(\mathrm{kg})$ & $56.4(9.1)$ \\
Aortic PWV $(\mathrm{m} / \mathrm{s})$ & $12.7(2.3)$ \\
Total choresterol $(\mathrm{mg} / \mathrm{dl})$ & $203.0(33.3)$ \\
hs-CRP $(\mathrm{ng} / \mathrm{ml})$ & $656.47(1450.38)$ \\
Interleukin-6 $(\mathrm{pg} / \mathrm{ml})$ & $1.21(0.94)$ \\
Serum amyloid A protein $(\mu \mathrm{g} / \mathrm{ml})$ & $4.65(8.04)$ \\
\hline Values are expressed as mean $\pm \mathrm{SD}$. & $\mathrm{n}=109$.
\end{tabular}

baPWV と, 臨床背景および炎症マーカーとの関係

表 2 は, baPWV と, 臨床背景および炎症マーカーとの 間に関連性があるかを Pearsonの相関係数を用いて評価 した結果である，既報のごとく，baPWV は，年齢 $\left(\mathrm{r}^{2}=\right.$ $0.40, p<0.001) \cdot$ 収縮期血圧 $\left(r^{2}=0.71, p<0.001\right) \cdot$ 拡張 期血圧 $\left(\mathrm{r}^{2}=0.40, \mathrm{p}<0.001\right)$ と強く相関した. 一方, baPWV は，動脈硬化の重要な危険因子の一つである血 清コレステロールとは相関しなかった. 炎症マーカーに 関しては, baPWV は hsCRP・IL-6 と相関したが, とくに IL-6 とより強く相関した $\quad\left(\mathrm{hsCRP} て ゙ は ~ \mathrm{r}^{2}=0.15, \mathrm{p}<\right.$ $0.001 ：$ IL-6 では $\left.\mathrm{r}^{2}=0.21, \mathrm{p}<0.001\right)$.

\section{PWV 階層別にみた炎症マーカー}

次に, hsCRP と IL-6 の 2 種類の炎症マーカーについ て, baPWVの階層ごとに平均して解析した. 年齢の影響 を最小限に抑制するため，年齢の 26〜 50\%值に該当する 41〜61 歳の参加者 44 例を対象とした. 対象を $\mathrm{baPWV}$ により次の 4 つの階層に分け, 9.3〜 $11.1 \mathrm{~m} / \mathrm{sec}(0 \sim 25 \%$ 值) を $\mathrm{A} 1 ， 11.2 〜 12.3 \mathrm{~m} / \mathrm{sec}$ (26〜 50\%值) を $\mathrm{A} 2,12.4$ $\sim 13.6 \mathrm{~m} / \mathrm{sec}(51 \sim 75 \%$ 值) を $\mathrm{A} 3 ， 13.7 \sim 21.0 \mathrm{~m} / \mathrm{sec}(76$ 〜100\%值) を A4 とした. そのうえで, hsCRP と IL-6 の 2 項目について, baPWV の階層間で差があるかを評価す るため, 分散分析 (Kruskal-Wallis one-way ANOVA) と 多重比較検定 (Wilcoxon rank-sum test) を行った。その

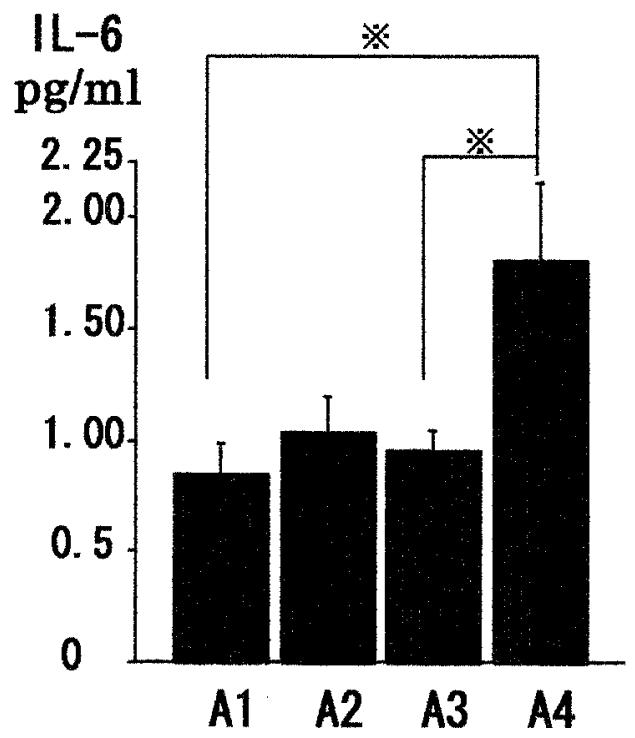

Fig 1. Relationship of baPWV with IL-6 concentrations.

$* \mathrm{p}<0.05$

Table 2 Relationships between PWV and indicated variables in study participants.

\begin{tabular}{lccc}
\hline & $\mathrm{r}$ & $\mathrm{r}^{2}$ & $\mathrm{p}$ \\
\hline Age & 0.64 & 0.40 & $<0.001$ \\
Systolic Blood Pressure & 0.71 & 0.71 & $<0.001$ \\
Diastolic Blood Pressure & 0.63 & 0.40 & $<0.001$ \\
Mean Blood Pressure & 0.70 & 0.49 & $<0.001$ \\
Total choresterol & 0.07 & 0.01 & N.S. \\
log-normalized hs-CRP & 0.39 & 0.15 & $<0.001$ \\
log-normalized Interleukin-6 & 0.46 & 0.21 & $<0.001$ \\
\hline
\end{tabular}

Table 3 Characteristics of participants according to quartile of PWV.

\begin{tabular}{|c|c|c|c|c|}
\hline \multirow{2}{*}{ Variable } & \multicolumn{4}{|c|}{ Quartile of PWV } \\
\hline & Al & A2 & A3 & A4 \\
\hline $\mathrm{PWV}(\mathrm{m} / \mathrm{sec})$ & $9.3 \sim 11.1$ & $11.2 \sim 12.3$ & $12.4 \sim 13.6$ & $13.7 \sim 21.0$ \\
\hline Age (y) & 51.2 & 52.8 & 50.8 & 54.1 \\
\hline hs-CRP (ng/ml) & 306.9 & 178.9 & 308.1 & 792.8 \\
\hline Interleukin-6 (pg/ml) & 0.85 & 1.04 & 0.95 & 1.81 \\
\hline Mean Blood Pressure $(\mathrm{mmHg})$ & 91.7 & 100.6 & 107.6 & 116.5 \\
\hline $\mathrm{T}$-choresterol (mg/dl) & 214.5 & 207.6 & 218.4 & 217.9 \\
\hline Height $(\mathrm{cm})$ & 158.9 & 156.8 & 160.7 & 162.3 \\
\hline Weight $(\mathrm{kg})$ & 53.7 & 55.0 & 57.0 & 64.5 \\
\hline
\end{tabular}


結果, IL-6 は, A4 群 (baPWV が $13.7 \mathrm{~m} / \mathrm{sec}$ 以上) におい て A1 群や A3 群 (baPWV が $13.6 \mathrm{~m} / \mathrm{sec}$ 以下) に比べて 有意 $(\mathrm{p}<0.05)$ な高值を示した (図 1). 各群間で年齢, 総 コレステロール，身長に有意差はなかったが, 平均血圧, 体重に有意差が認められた (ANOVA; 年歯 : $p=0.37$, 総コレステロール : $p=0.86$, 身長: $p=0.34$, 平均血圧 : $\mathrm{p}=0.002$, 体重 : $\mathrm{p}=0.02$ ) (Table 3). このため, 血圧や体 重の炎症マーカーへの関与は否定できない.

\section{考 察}

筆者らは，健康な地域住民を対象として，baPWV と， 臨床背景や炎症性マーカーとの関連性について検討し, 以下のような結果を得た。1 ) 心筋梗塞や狭心症などの ない健常人においても baPWV・hsCRP・IL-6 は加齢と ともに増大した． 2 ) baPWV は hsCRP・IL-6 と強く相 関するが，とくに baPWV が $13.7 \mathrm{~m} / \mathrm{sec}$ を超えると IL-6 は急速に増加した. 3 ) baPWV は hsCRP に比べて IL-6 とより強く相関した，4 ) 既報のごとく, baPWV は血清 総コレステロールと相関しなかった. 以上から, 本研究 で測定した炎症マーカーである hsCRP・IL-6 は, 健康な 地域住民のなかでも, baPWV が正常高值となる極めて 初期の動脈硬化例において高值を示す可能性が示唆され た.

hsCRP・IL-6 などの炎症マーカーは心血管病の独立し た予知因子である. ${ }^{14}$ 現在までに, 動脈硬化と炎症マ一 カーとの関係を検討した研究は多数みられるが，その殆 どは急性心筋梗塞や不安定狭心症などで入院治療を要す る患者を対象に行われたものである，健康診断や人間 ドックなどの健常人を対象とした研究は少数である. Yasmin $ら^{13}$ は，健常人 427 例を対象として baPWV と hsCRP との関連性を検討した. それによると, 糖尿病, 高 脂血症, 腎臓病, 心血管病, 高血圧などを除外した健常人 でも, hsCRP は動脈硬化の独立した危険因子になりうる という。健康な地域住民を対象とした本研究でも, baPWV は hsCRP・IL-6 と有意な相関を示し，とくに baPWV が $13.7 \mathrm{~m} / \mathrm{sec}$ を超えると IL-6 は上昇した.この ような結果から, 冠動脈疾患を発症して動脈硬化が顕在 化する以前に, 血管の炎症が動脈硬化を進行させている 可能性が高い.

本研究では, baPWV は hsCRP に比べて IL-6 とより 強く相関した. 最近の研究によって, 動脈硬化病変にお ける IL-6 遺伝子の過剩発現が報告された. ${ }^{15}$ IL-6 は，血 管における炎症反応の過程でマクロファージ，内皮細胞， 線維芽細胞から産生され，単独で，あるいは他の炎症性 サイトカインであるインターロイキン 1 (IL-1) や腫瘍 壊死因子 $\alpha\left(\mathrm{TNF}^{-} \alpha\right)$ と協調して, 肝臓において hsCRP・血清アミロイド A 蛋白などの急性期蛋白の産生

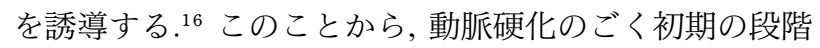
から, 血中 hsCRP・血清アミロイド A 蛋白の上昇に先 立って血中 IL-6 が既に上昇している可能性が高く, 動 脈硬化の早期発見に IL-6 が有用であると思われる. 米 国の健常人を対象とした疫学研究は, 血中 IL-6の上昇 が将来の心筋梗塞の発症予知につながると報告してい る. baPWV が心血管イベント予知因子であることを考 え併せると, ${ }^{17}$ 本研究の結果は, わが国の健常人において も IL-6 が心血管イベント予知因子に有用であることを 示唆する.

血清総コレステロール值の上昇は動脈硬化の成因とし て重要であるが, 本研究ではbaPWV は総コレステロー ル值と相関しなかった．この結果は，65～84 歳の高血圧 患者を対象とした Dart ら ${ }^{20}$ の報告とも一致する.それに よると, 血清総コレステロールと大動脈のコンプライア ンスの間には相関関係を認めなかった. 一方, 酸化 LDL が血管壁に侵入する際, 単球や $\mathrm{T}$ リンパ球が重要な役割 を示すことから ${ }^{5}$ 総コレステロールと炎症マーカーとの 間に相関関係の存在が予測されたが, 本研究では, 総コ レステロールは, hsCRP・IL-6 と相関関係を認めなかっ た. Ridker ら 18 の検討によれば，健常人においては hsCRP と LDL コレステロールの間の相関関係は弱く, それぞれが心血管病の独立した予測因子であるという. 総コレステロールと炎症マーカーはともに冠動脈疾患の 予知因子ではあるが, 動脈硬化の病変形成の過程におけ る役割は異なると考えられた。

今回, 健常人に扔いても, 炎症が初期段階の動脈硬化 を進展させるひとつの因子であることが示唆された. 炎 症マーカーの測定は, 採血のみで可能なことから, 動脈 硬化の早期診断としては簡便性および利便性が高い.心 血管病のような生活習慣病においては, 生活習慣の改善 に対する患者のモチベーションをいかに高い状態で長く 持続させるかが，治療や予防の成否を大きく左右する。 筆者らの今回の試みのように, 地域で健康相談を行い, 簡易検査によって動脈硬化の進展度を評価することは, 住民が個々の生活習慣を見直す，又とない機会となるで あろう。

\section{文献}

1. 長谷川元治 脈波速度法 (PWV) による動脈硬化度の評 価. 日本臨床 $1997 ； 55$ Suppl 1：688-690.

2. 山科章, 冨山博史. 高血圧性臟器障害とその対策. 基礎・ 臨床研究の新情報. 高血圧性臟器障害の病態・診断学. 動 脈硬化病変と脈波速度 (PWV) (解説 / 特集) 2004；62： 80-86.

3. Blacher J, Guerin AP, Pannier B, et al. Impact of aortic stiffness on survival in end-stage renal disease. Circulation 1999 ; 99 : 2434-2439. 
4. Laurent S, Boutouyrie P, Asmar R, et al. Aortic stiffness is an independent predictor of all-cause and cardiovascular mortality in hypertensive patients. Hypertension 2001 ; 37 : 1236-1241.

5. Ross R. Atherosclerosis - an inflammatory disease. N Engl J Med 1999; 340 : 115-126.

6. Libby P. Inflammation in atherosclerosis. Nature $2002 ; 420: 868-874$

7. Sakamoto H, Aikawa M, Hill CC, et al. Biomechanical strain induces class a scavenger receptor expression in human monocyte/macrophages and THP-1 cells: a potential mechanism of increased atherosclerosis in hypertension. Circulation 2001; $104: 109-114$.

8. Liuzzo G, Biasucci LM, Gallimore JR, et al. The prognostic value of $\mathrm{C}$-reactive protein and serum amyloid a protein in severe unstable angina. N Engl J Med 1994; $331: 417-424$

9. Ridker PM, Rifai N, Pfeffer MA, et al. Inflammation, pravastatin, and the risk of coronary events after myocardial infarction in patients with average cholesterol levels. Cholesterol and Recurrent Events (CARE) Investigators. Circulation 1998; 98 : 839-844.

10. Yasojima K, Schwab C, McGeer EG, et al. Generation of $\mathrm{C}$-reactive protein and complement components in atherosclerotic plaques. Am J Pathol 2001 ; 158 : 10391051.

11. Doo YC, Han SJ, Lee JH, et al. Associations among oxidized low-density lipoprotein antibody, C-reactive protein, interleukin-6, and circulating cell adhesion molecules in patients with unstable angina pectoris. Am
J Cardiol 2004 ; 93 : 554-558.

12. London GM, Marchais SJ, Guerin AP, et al. Inflammation, arteriosclerosis, and cardiovascular therapy in hemodialysis patients. Kidney Int Suppl 2003 : S88-S93.

13. Yasmin, McEniery CM, Wallace $\mathrm{S}$, et al. C-reactive protein is associated with arterial stiffness in apparently healthy individuals. Arterioscler Thromb Vasc Biol 2004 ; 24 : 969-974.

14. Tzoulaki I, Murray GD, Lee AJ, et al. C-reactive protein, interleukin-6, and soluble adhesion molecules as predictors of progressive peripheral atherosclerosis in the general population: Edinburgh Artery Study. Circulation $2005 ; 112$ : 976-983.

15. Rus HG, Vlaicu R, Niculescu F. Interleukin-6 and interleukin-8 protein and gene expression in human arterial atherosclerotic wall. Atherosclerosis 1996; 127 : 263-271.

16. Heinrich PC, Castell JV, Andus T. Interleukin-6 and the acute phase response. Biochem J 1990; 265: 621636.

17. Meaume S, Benetos A, Henry OF, et al. Aortic pulse wave velocity predicts cardiovascular mortality in subjects $>70$ years of age. Arterioscler Thromb Vasc Biol $2001 ; 21: 2046-2050$.

18. Ridker PM, Rifai N, Rose L, Buring JE, Cook NR. Comparison of $\mathrm{C}$-reactive protein and low-density lipoprotein cholesterol levels in the prediction of first cardiovascular events. N Engl J Med 2002; 347: 15571565. 


\title{
The Relationship between Pulse Wave Velocity and Serum Inflammatory Markers among Healthy Adults in a Community
}

\author{
Hiroko Sato, ${ }^{1,2}$ Mahito Sato, ${ }^{1,3}$ Hironosuke Sakamoto, ${ }^{1,4}$ \\ Yoshie Sawada, ${ }^{1}$ Ayami Hoshino, ${ }^{1}$ Yukiko Miyazaki, ${ }^{5}$ \\ Kumiko Sato, ${ }^{5}$ Toshiaki Kogure, ${ }^{3}$ Masahiko Kurabayashi ${ }^{6}$ \\ and Junichi Tamura ${ }^{1}$ \\ $\begin{array}{ll}1 & \text { The Department of General Medicine, Gunma University Hospital } \\ 2 & \text { The Department of Integrated Japanese Oriental Medicine, Gunma University School of Medicine } \\ 3 & \text { Neuromuscular and Developmental Anatomy, Gunma University Graduate School of Medicine } \\ 4 & \text { Takasaki University of Health and Welfare } \\ 5 & \text { Gunma University School of Health Sciences } \\ 6 & \text { Department of Medicine and Biological Science, Gunma University Graduate School of Medicine }\end{array}$
}

Background and Aims : Brachial-ankle pulse wave velocity (baPWV) and serum inflammatory markers, such as high-sensitive C-reactive protein (hsCRP) and interleukin-6 (IL-6), are non-invasive approaches for evaluating the severity of atherosclerosis. This study was conducted to elucidate the relationship between baPWV and serum inflammatory markers among healthy adults in a community. Methods : We measured baPWV and serum concentrations of hsCRP and IL-6 in 109 healthy adults who attended health counseling in Yoshioka-town, Gunma, Japan. We statistically analyzed the relationship of baPWV with serum inflammatory markers.

Results : The positive correlation was found between baPWV and the two inflammatory markers, hsCRP and IL-6. The coefficient rates in IL-6 was higher than that in hsCRP. Serum IL-6 concentrations were significantly higher in the adults with baPWV $\geqq 13.7 \mathrm{~m} / \mathrm{sec}$ than in those with baPWV $<13.7 \mathrm{~m} / \mathrm{sec}$. Conclusions : Vascular inflammation may cause subclinical atherosclerosis in healthy adults in a community. The serum inflammatory marker, particularly IL-6 may be a useful measure of subclinical atherosclerosis. (Kitakanto Med J 2006; 56:201 206)

Key Words: healthy adults, pulse wave velocity, interleukin-6, hs-CRP, atherosclerosis 